PLANTS PEOPLE

POSSIBILITIES

\title{
Silver Leaf Disease. Stereum purpureum
}

\section{Author(s): J. Bintner}

Source: Bulletin of Miscellaneous Information (Royal Botanic Gardens, Kew), Vol. 1919, No. 6/7 (1919), pp. 241-263

Published by: Springer on behalf of Royal Botanic Gardens, Kew

Stable URL: http://www.jstor.org/stable/4111529

Accessed: 25-06-2016 02:55 UTC

Your use of the JSTOR archive indicates your acceptance of the Terms \& Conditions of Use, available at

http://about.jstor.org/terms

JSTOR is a not-for-profit service that helps scholars, researchers, and students discover, use, and build upon a wide range of content in a trusted digital archive. We use information technology and tools to increase productivity and facilitate new forms of scholarship. For more information about JSTOR, please contact support@jstor.org.

Royal Botanic Gardens, Kew, Springer are collaborating with JSTOR to digitize, preserve and extend access to Bulletin of Miscellaneous Information (Royal Botanic Gardens, Kew) 
ROYAL BOTANIC GARDENS, KEW.

B U L LETIN

OF

MISCELLANEOUS INFORMATION.

Nos. 6 \& 7]

$[1919$

\section{XVI.-SILVER LEAF DISEASE.*}

Stereum purpureum.

J. Bintner.

(With Plate.)

I.-Introduction.

"Silver leaf" is notorious not only for the serious damage which it causes to fruit trees but also for the controversies concerning the nature of the disease.

The first observations were made by Prillieux (1) 1885 in France, and published under the title of "Le Plomb des arbres fruitiers." $\mathrm{He}$ considered the leaden colour of the leaves to be the result of the presence of large air spaces between the epidermal and palisade cells; he also noticed larger epidermal cells in the infected leaves than in the normal leaves. In 1886 Sorauer (2) referred to the "Milchglanz" of fruit trees, and again Aderhold (3) in 1894, mentioned it as occurring in Germany. Both these authors considered "Silver leaf" of fruit trees as of nonparasitic character. This theory however became very improbable on the discovery, made in England by Percival (4), who in 1901 applied the name "Silver leaf", to the disease, that fungal hyphae existed in the wood of silvered plum-trees. Successful inoculation experiments by Percival, who proved that silvering could be caused by the fungus Stereum purpureum, did not however convince all his contemporaries. Massee (5), for instance, still attributed the disease to some physiological disturbance. Delacroix (6) erroneously states that Percival had described Stereum hirsutum as the cause of silvering, and even adds: "Malgré l'affirmation de cet auteur (Percival), nous ne pouvons, jusqu'à plus ample informé, admettre de telles conclusions." Blackmore (7) in commenting on this disease in his report on New Zealand diseases, states that "Silverblight certainly is becoming very prevalent in a number of orchards in North Otago and elsewhere. Often where fruit trees are making succulent growth it spreads rapidly, killing trees within

* This research was carried out in the Laboratories of the Department of Plant Physiology and Pathology. Imperial College of Science and Technology, South Kensington. Mr. Bintner was formerly a Sub-Foreman in the Royal Botanic Gardens.-En.

(480.) Wt. 15\&-829. 1,125. 9/19. J. T. \& S., Ltd. G. $14 . \quad$ Sch. 12. 
Kew Bulletin, 1919.]
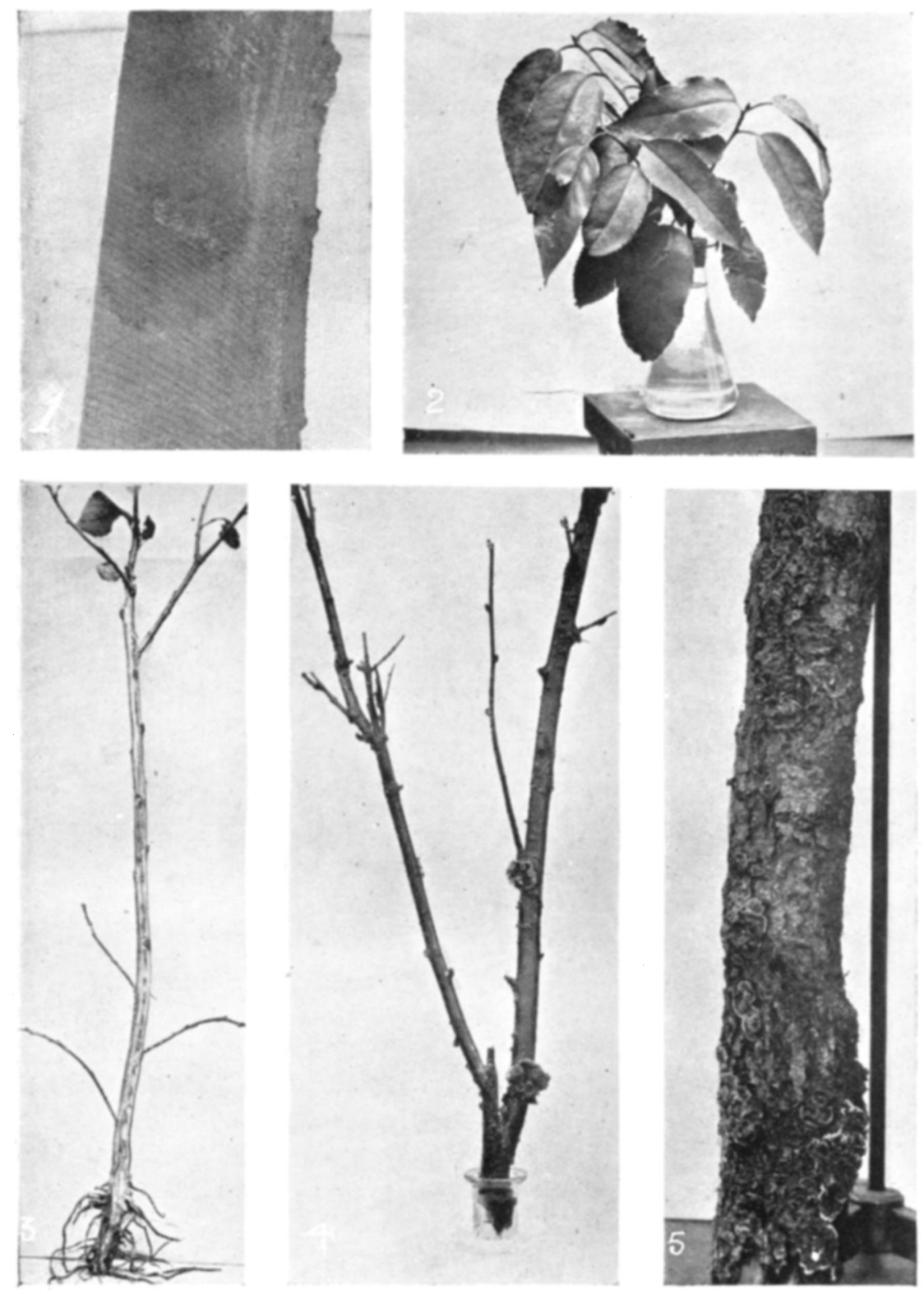

VIII.

To face page 241.] 
two years. For a long time I have noticed that with fruit trees which have been killed by Silverblight, there occasionally appears on the stem or branches some time after the death of the tree the fructification of a fungus; but so much has been said in reference to Silverblight being due to bacteria that I do not think the roundish disc-like fungus growths are cornected with Silver leaf disease." Later he adds: "I however forwarded specimens to England to a friend, who identifies them as the same fungus which is considered by Professor Percival and others to be the cause of Silver leaf disease of fruit trees in the United Kingdom." The above quotations clearly indicate the scepticism of a number of workers with regard to Percival's discovery. The latter's views were, however, confirmed by Pickering (8) at Woburn during 1906-1909, as the result of a large number of successful inoculations of various fruit trees and a few other trees and shrubs with Stereum purpureum. Similar results, with equal success, were obtained in the detailed work at Cambridge and Merton of Brooks (9). Güssow (10) observed Silver leaf in Canada and repeated with success similar inoculation experiments. The latest contributions on Silver leaf bv Smolak(11) leave that author still doubtful as to $S$. purpureurn being the sole cause of Silver leaf. He discovered bacteria in silvered leaves, but he considered them of secondary nature.

In view of the wide distribution of this insidious disease, throughout the continent of Europe, from England to the Balkans, and in America, where, according to Güssow (12) it is prevalent in Canada, from St. John's, Newfoundland to Vancouver Island, and also in.Australia and New Zealand, it is plain that Silver leaf is very likely to hamper considerably the fruit growing industry throughout the world unless prompt action is taken to cope with the disease. Unfortunately in England the best varieties of cultivated plums are most susceptible to Silver leaf, as can be judged from the plum orchards in Surrey, Middlesex, Kent, and Worcestershire, where in certain plantations 60-95 per cent. of the plum trees of "Victoria" and "Czar" varieties have been so severely attacked that wholesale grubbing out of these trees has had to be resorted to.

The following gives a list of plants known to be affected by Silver leaf :-

Those marked with ${ }^{*}$ have been observed by the author, those marked $* \dagger$ are new records.

Rosaceae.

* +1 . Neviusia alabamensis, A. Gray.

*2. Spiraea japonica var. glabrata, Lange.

3. Philadelphus sp.

4. Exochorda sp.

5. Pyrus Malus-cultivated varieties of Apples.

*Lord Grosvenor. Newton Wonder.

*Bramley's Seedling. Lord Suffield.

P. prunifolia.

*P. triloba, Lindley. var. flore pleno. 
*6. Prunus Amygdalus, Stokes, and cultivated varieties of Almonds.

P. Armeniaca, Linn. and cultivated varieties of Apricots.

*P. Avium, Linn., Gean.

*P. Cerasus, Linn. and cultivated varieties of cherries.

*P. communis, Hudson. Wild Plum.

$\dagger P$. japonica, Thunberg.

*P. lusitanica, Linn. Portugal Laurel.

*P. spinosa, Linn. Sloe.

* $+P$. acida, Ehrhart. var. flore pleno.

7. Cultivated varieties of Plums:-

Pond's Seedling.

Monarch.

Gisborn.

Several gages.
*Victoria.

*Czar.

*Belgian Purple.

*Damsons.

8. Stocks used for grafting :-

* The Brompton.

*+Myrobella (Prunus myrobolanus).

* + Common Plum stock var.

Saxifragaceae.

* + Ribes cereum, Douglas, and cultivated varieties of Gooseberries and Currants.

Leguminoseae.

*Laburnum vulgare, Presl.

$*+L$. alpinum, Presl.

Oleaceae.

Syringa sp.

Sapindaceae.

Aesculus Hippocastanum, Linn.

$*+A$. carnea, Hayne. var. Briotii.

Ericaceae. •

*+Pernettya mucronata, Gaudich.

† Noted by Mr. F. J. Chittenden at the R.H.S. Gardens, Wisley.

All material used for examination, as described in this paper, was secured from naturally infected "silvered" plants growing in the open, not from artificially inoculated plants, nor from branches which had been killed by the fungus. The plants were marked in the field during the summer of 1918, and from October onwards, and material was taken, as required, to the laboratory. Unfortunately the leaves could not in all cases be examined, as the majority of plants were of a deciduous character, so that the leaves had dropped before the microscopic details could be studied.

The tracing of the fungus in diseased tissues is by no means an easy task, owing to the fact that the hyphae are extremely fine. The following method was adopted:-The material was cut into cubes of about $1 \mathrm{~cm}$. and steeped for 6-8 days, or even a fortnight according to the nature of the material, in a saturated solution of picric acid in 50 per cent. alcohol. For sections, 
soaking for 4-6 hours is sufficient. The excess of picric acid is washed off and the section stained with concentrated Delafield haematoxylin (ripe solution) for at least 4-6 hours, or preferably overnight, according to the nature of the material. Picric acid stains lignified tissues a yellow-citron, and haematoxylin imparts a blue colour to the hyphae.

In the following account a description is given of the diseased condition as found in the following plants, in which the hyphae of Stereum purpureum have been observed.

\section{II.-Specific CaSes.}

(1) Victoria Plum.-The Plum orchards in the Brentford and Heston district of Middlesex suffered severely from Silver leaf during 1918; eighty to ninety per cent. of the plum trees (of ages from 5-30 years), chiefly the varieties "Victoria" and "Czar," were so severely affected that they had to be cut down during late summer and early autumn. Owing to a scarcity of labour the sawn-off branches and tree-stumps were not removed from the plantations. The first fructifications of $S$. purpureum developed during the last week of September on this dead wood and also on silvered trees still standing. Undoubtedly diseased wood in the plantations will endanger plum and other trees in the neighbourhood. 'The plum trees met with in the orchards of this locality were mainly grafted on the "Brompton" and " common plum" stocks. Generally where suckers grew up from the stocks of silvered plants, they showed silvering relatively to the same extent as the scion, and this irrespective of the age of the plum tree. In a few cases, however, I noticed normal suckers of "Brompton" and "common plum" stock coming up from silvered trees. Healthy suckers were most common on partially silvered plants, that is, where onlv localised branches of a tree were attacked, mainly where only the upper set of branches was affected by the disease. I also noticed on a few completely silvered trees healthy suckers of the above varieties arising from the stocks. Silvered suckers, one year old, to the number of 150, were dug up and their roots examined; 10 of these were taken to the laboratory, and $140^{*}$ were examined in the field. Of the latter 26 appeared normal to the naked eye in roots and stem, whereas the remaining 116 revealed discoloration of the tissues in cross section of roots and at the base of the stem. A few two-year-old suckers were also examined and the discoloration was still more obvious. The discoloration in the 10 suckers mentioned above could easily be traced up the suckers for twothirds to three-quarters of their length. The discoloration usually consisted of 2-4 reddish brown streaks which sometimes ran parallel, but frequently followed a winding or twisting path in the stem. The streaks were confined to the outermost xylem.

The following table indicates the height reached by the discoloration and by the hyphae in five one-year-old suckers.

* These 140 suckers have been planted in the experimental plot of the Royal Horticultural Society Gardens, Wisley. 


\begin{tabular}{|c|c|c|c|c|c|}
\hline Number of Sucker. & 1. & 2. & 3. & 4. & 5. \\
\hline Total length of sucker from its point of & $\begin{array}{c}\mathrm{cm} \\
110\end{array}$ & $\begin{array}{l}\mathrm{cm} . \\
140\end{array}$ & $\begin{array}{l}\mathrm{cm} . \\
102\end{array}$ & cm. & $\begin{array}{c}\mathrm{cm} . \\
95\end{array}$ \\
\hline $\begin{array}{l}\text { Height reached by the discoloration } \\
\text { visible to the naked eye }\end{array}$ & 65 & 83 & 52 & 51 & 60 \\
\hline Height reached by the hyphae $\ldots$ & 62 & 79 & 51 & 47 & 58 \\
\hline
\end{tabular}

For some little distance above the point where the brown streaks cease to be visible to the naked eye the microscope shows scattered patches of brownish material in the vessels.

In completely silvered trees and in those where the lowest set of branches (the first branches developed on the stem) were infected the discoloration was continuous from the twigs into the branches, down the main stem, through the point of union between scion and stock, into the superficial roots of the latter, and from these roots it could be traced again upwards into the stem of the sucker.

In agreement with previous workers, I found that no trace of hyphae could be observed in the leaves or petioles of silvered plum trees and suckers. Hand-sections made from the discolored zone of the root stock, branches and twigs, and of the roots and stems of suckers, disclosed the exceedingly minute hyphae which, when stained, could be seen invading the wood vessels in all directions. In suckers the fine hyphae extend from the cambial region inwards into the wood parenchyma; they sometimes keep a straight course in the discoloured vessels, but occasionally branch when a few filaments may trespass upon the yellowish-brown deposit of the cell-cavity. The hyphae do not seem to enter a vessel at any particular spot, since they can be seen passing across the lignified walls in their thickest parts, and they develop luxuriantly in the lumen of the vessels. They rian also be traced in the intercellular spaces, as in Text fig. 1,

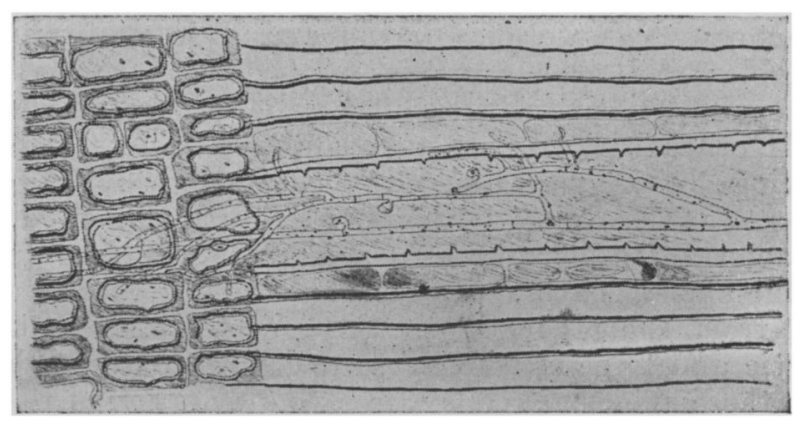

Text fig. 1.-Longitudinal section through the wood of a silvered plum sucker, Brompton stock.

in fact, wherever there is room for development. In the living tissue no hyphae were found outside the cambial region; but in 
branches or superficial roots which have been killed by the fungus, and where there is an indication of the fructifications beginning to pierce the bark, the hyphae are naturally present in practically all the tissues. The hyphae are septate, and clamp connections frequently occur (see Fig. 1). The brown material on which the discoloration depends is found mainly in the xylem vessels, but some cavities and the walls of the medullary ray cells are also stained, as well as certain cambium cells.

(2) Prunus lusitanica.-Among the evergreen members of the Pruneae, this is the only species which up to the present has been found to suffer from Silver leaf disease. The material selected for the present investigations was secured from the Prunus collection in the Royal Botanic Gardens, Kew. On individual plants several branches showed silvering, the youngest leaves of the current year's growth seeming to be most severely attacked. The curling over of these leaves rendered them very noticeable at a distance. The upper and lower epidermis were found in many instances to be loosened and even hanging in shreds as a result of contact with other branches and leaves (see Plate). The previous year's leaves and also those of early spring growth, though severely affected, did not display any curling or blistering. The upper and lower epidermis of such diseased leaves could be peeled off with a penknife with comparative ease. On cutting off branches from one to five years old a conspicuous discoloration was to be observed in the region of the outer xylem; only in branches five to ten years old, however, did the discoloration extend into the older xylem. A branch which had its origin below ground was cut off immediately above the soil level; three weeks later, towards the end of September, fructifications of $S$. purpureum developed on the cut surface of the part of the branch still attached to the plant, the fructifications taking their origin from the region of the young wood. Another 8 in. was then cut off and in turn fructifications were produced 23 days later on the surface so exposed.

Satisfactory hand sections of the curled leaves were clearly unobtainable; and even from less infected leaves no suitable sections could be cut, without the cells of the tissue falling apart. In order to avoid the separation of the cells, the material, after fixing in strong Flemming's fluid, was imbedded in paraffin. When staining with E. F. Smith's method, I perceived bacteria-like structures in a few of the lower epidermal cells of the curled leaves. As the epidermis of these leaves was detached from the other tissue, these bacteria are most likely saprophytic and to be considered secondary in nature; they were absent in those epidermal cells where no dissolution of the middle lamella had taken place. No hyphae could be seen in any part of the leaves or petioles either in cross or longitudinal sections. In one-year-old twigs a few threads occasionally passed from the cambial layer into the bast parenchyma, causing discoloration of the latter, but the hyphae were most prevalent in the primary wood vessels, which in turn showed distinct discoloration. 
(3) Prunus triloba var. flore pleno.-In 1916 localised silvering appeared on a few individual plants of this variety which were growing in a bed at Kew; but in the late season of 1918 the disease had spread to many other plants in the same bed, a few of which were completely silvered. In December several silvered branches were cut off and examined. When removing the bark with a pocket-knife the peculiar discoloured streaks were noticeable again, similar to those mentioned under "Victoria Plum." In the case of one three-year-old branch these discoloured streaks were followed. upwards into the terminal bud of the current year's growth. A very characteristic feature in the silvered branches of Prunus triloba is that the bark can be stripped off with comparative ease. On two shrubs Stereum purpureum fructifications were developing.

Owing to the season being so far advanced, no leaves could be examined. When cutting hand sections of the diseased stem, the same difficulty in obtaining intact slices was experienced as with silvered leaves of "Victoria Plum." Abnormal air spaces occurred in the bast of affected twigs. The cambial cells and the cells of the adhering tissues fell apart from the xylem. Isolated, single phloem-parenchyma cells were found floating free on the slide; thus the separation of these cells resembles the separation of the mesophyll cells of the leaves, resulting apparently from the same cause,/namely, the dissolution of the middle lamella. In the three-year-old branch mentioned above, the hyphae were traced to within a centimetre of the terminal bud. Text Fig 2 indicates hyphae in the xylem vessel.

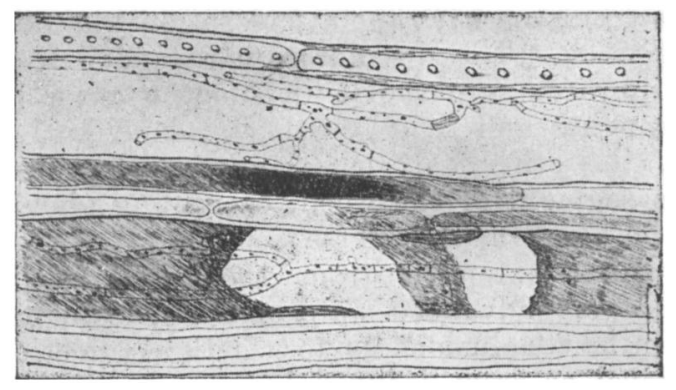

Text fig. 2.-Longitudinal sectior of Prunus trilola var. flore pleno, showing hyphae in the xylem vessels bordering the cambium.

The severe pruning to which this variety of Prunus is annually subjected immediately after flowering undoubtedly increases the opportunities for the entrance of the fungus.

(4) Apple Trees.-In October, 1918, Messrs. White \& Sons, Paddock Wood, Kent, forwarded to me twigs and leaves of " Grenadier" and "Lord Grosvenor" apple trees which were attacked with Silver leaf. It was practically impossible to cut entire hand sections of the leaves of "Lord Grosvenor" without the tissue falling apart, owing to the fact that they exhibited a phenomenon similar to that of the leaves of plums. The 
upper epidermal cells separated as a layer from the palisade cells; the palisade cells fell apart and were found to be filled with a brownish coloured material which gave a silver-brown appearence to the leaves. No hyphae were to be obtained in the leaves or petiole, nor could they be traced in any of the twigs which measured less than 8 in. in length, although these twigs showed on cutting conspicuous discoloration from the basal end upwards.

The variety "Grenadier" was only slightly attacked, and instead of a shiny grey brownish tint on the upper surface, as in "Lord Grosvenor," the leaves were a dark leaden colour. There was no separation or falling apart of the epidermal or palisade cells. In hand sections, the leaves seemed almost normal, with the exception of a reduction in chloroplasts, and there was no sign of discoloration in the twigs. Although I was unable to examine the trees in the field, it is presumable from the information received, together with the above observations, that the apparent silvering in the variety "Grenadier" cannot be attributed to the action of a foreign organism; the lead colour is probably due to some physiological weakness of the tree.

Early in January, 1919, I observed a tree, stated to be " Bramley's Seedling," growing in a cottage garden at New Cross, London, which produced numerous confluent masses of fructifications of Stereum purpureum on a side-branch towards the base of the stem; the branches developing immediately above this on the same side of the tree produced also tiny scattered tufts of the fungus. On cutting off the lowest branch near the stem, the characteristic browning could be seen at the amputated ends, and on removal of the bark the discoloration was found to extend down to the roots. The discoloration extended from the superficial roots upwards into the main stem, whence it passed into the main branches and twigs, affecting about half of the crown of the tree, the other half being apparently normal. In the main stem a segment of the wood, occupying about one quarter of the whole area in transverse section, showed marked discoloration which extended from the cambium to the pith. Owing to the very advanced state of the disease it was difficult to draw definite conclusions as to whether infection took place below soil level or from injured branches. Curiously enough, the diseased part of the tree had suffered severely during the last few years from "American Blight" (Eriosoma lanigera); the damage caused by these insects was very marked on the branches and the twigs, as shown by the presence of intumescences and abnormal growth. It is highly probable that the punctures and the subsequent wounds produced by this insect facilitated the penetration of $S$. purpureum.

Well-developed mycelium in the twigs, branches and main stem was to be observed in longitudinal sections of the discoloured wood. The fine threads could be easily traced from the branches into the fruiting spurs, but with greater difficulty in the oneyear-old twigs; the hyphae branched frequently and were of irregular thickness (see Text Fig. 3). They were found more abundantly in the external layers of xylem than in the inner; 
and they were particularly abundant in the scattered vessels or tracheids which contained no brown material. In the medullary rays the "browning" of the cells was very irregular, some of

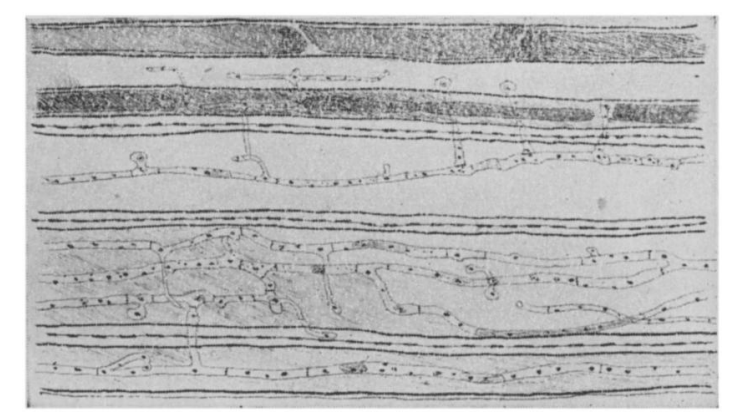

Text fig. 3.-Hyphae of Stereum in the wood vessels of apple, "Bramley's Seedling."

the cells containing hyphae having brown walls and contents, while others, which contained hyphae, were otherwise unaltered.

(5) Spiraea japonica var. glabrata (sp. glabrata).--In October, 1918, I observed one silvered shoot of the current year's growth in one plant amongst 33 others growing at the Royal Botanic Gardens, Kew. This Spiraea belongs to the section which is pruned to about 4 to 6 inches above the ground. The first two buds lying below the point of pruning were dead, and the silvered shoot had developed from the next bud at a point about $5 \mathrm{~cm}$. below the cut surface. On splitting the branch which bore the silvered shoot, slight discoloration of the wood could be traced from a point about $3 \mathrm{~cm}$. below the silvered shoot to its point of origin, and then up that shoot to a height of $4 \mathrm{~cm}$.

The leaves could not be examined. microscopically. In the roots and in other parts of the shoot no trace of hyphae was to be seen except in the discoloured tissues. The hyphae were followed downwards for $5 \mathrm{~cm}$. from the point of pruning, and for about $3.5 \mathrm{~cm}$. up the silvered shoot. The discoloration was everywhere more extensive than the distribution of the hyphae; the latter occurred at the periphery of the wood, whence they could be traced inwards, branching in all directions and. occasionally developing clamp connections (see Text Fig. 4).

From the above observations, it is evident, in this particular instance, where only one shoot out of many on the same bush and amongst other plants in the same bed became silvered, that the fungus had penetrated through a wound caused by pruning.

(6) Neviusia alabamensis.-During the late summer of 1918, a plant of this species growing at $\mathrm{Kew}$, was noticed to be silvered. It was not examined until November, when a silvered plant was dug up, with its roots, for laboratory investigations. The root stock had suffered injury and was distinctly discoloured; a part 
of it had already been killed. On splitting the shoot so as to expose the pith, it was noticed that the discoloration was found throughout the wood but it was most marked towards the pith.

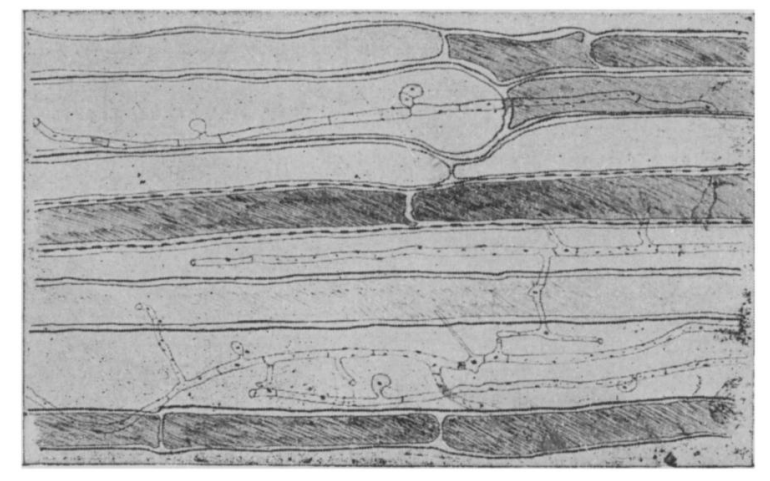

Text fig. 4.-Longitudinal section of Spiraea japonica var. glabrata, showing byphae in the wood.

The discoloration could be traced upwards to a point $90 \mathrm{~cm}$. above the root stock, but the last $20 \mathrm{~cm}$. of the shoot displayed no discoloration. 'Three other silvered shoots were cut off above ground, measuring from their point of last year's pruning, 140, 135 , and $150 \mathrm{cms}$. respectively; curiously enough on splitting these shoots the discoloration was found to be absent from the base upwards to a height of 40,45 , and $63 \mathrm{cms}$. respectively; the browning then gradually increased in an upward direction towards last year's point of pruning. The absence of discoloration at the base of these three shoots suggests that the fungus had entered through the wounds caused by pruning.

The nature of the discoloration of infected material varies within the tissues and according to the host. In the roots of. Neviusia the discoloured cells assume various colours, from a purplish red to magenta, seldom a reddish brown (see Text Fig. 5). In the stem, the purple and magenta colour are re.placed by a reddish pink, passing over to a dark brown. Abundant hyphae were present in the wood generally, but they were predominant in the xylem elements bordering the pith. (Text Fig. 6.) This is probably owing to the fact that there is greater aeration in the pith region. No hyphae were noticed beyond the discoToration, which proves that the fungus has penetrated in the one case through the injured root stock, and in the other three cases as a result of pruning.

(7) Ribes cereum.-While examining the bed of Portugal Laurel in Kew Gardens, already referred to, my attention was. drawn to a plant of Ribes cereum growing about $26 \mathrm{ft}$. distant. On a single shrub four branches of the current year's growth exhibited silvering; one of these, a sucker, was taken to the laboratory. The remaining three shoots had developed at different heights from the ground; they were cut up into suitable 
lengths for propagation and inserted, in order to see to what extent silvering may be transmitted by vegetative propagation.*

The discoloration in the wood was very slight and could only be seen with a pocket lens; it was traced for a distance of $18 \mathrm{cms}$. up the silvered sucker.

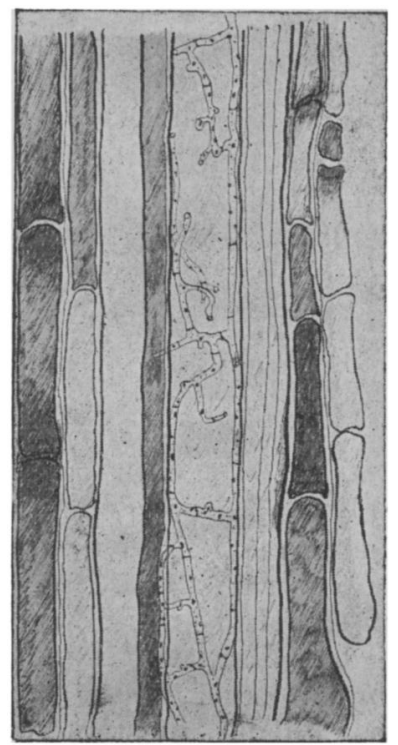

Text fig. 5.-Longitudinal section of root of Neviusia alabamensis.

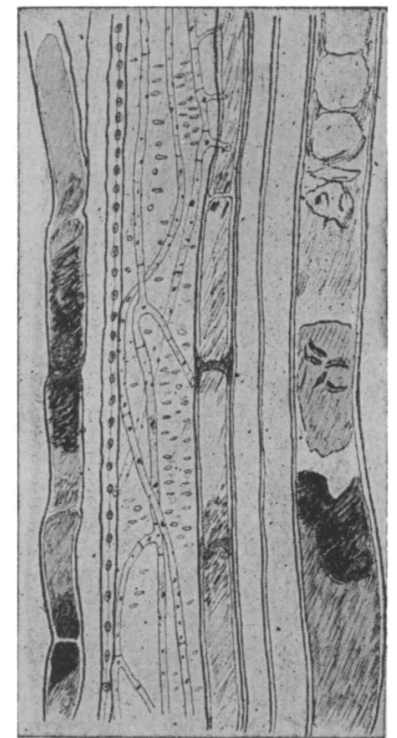

Text fig. 6.-Isongitudinal section of a shoot of Neviusia alabamensis.

The hyphae were followed to within $2 \mathrm{~cm}$. of the upper limit of the discoiloured wood. In the silvered branches the inner wood elements are stained pink, passing over to bluish magenta towards the cambial region, whereas the cavities of the phloem and medullary rays cells are filled with a dark brown mass. Very few hyphae were seen in the central wood elements, but abundant threads were present in the elements bordering the cambial region (see Text Fig. 7). It was difficult to cut entire hand sections, as the xylem invariably separated from the bast; the cambial cells showed localised disorganisation as a result of the invading hyphae; the bast parenchyma also was somewhat affected and easily broke up, but no hyphae were observed in it.

The leaves were not examined and no fructifications of Stereum purpureum were noted anywhere on this partially silvered plant, but the characters of the hyphae were identical with those of other hosts, and those of mycelium grown in artificial cultures. Whether shoot as well as root infection took place in this plant cannot definitely be stated, but since browning could be traced from the root-stock into the lower part of the sucker only, it is certain that in this case the fungus gained entry through the injured root-stock.

\footnotetext{
* 15 cuttings were inserted in a cold frame in the Royal Botanic Gardens, Kew, all of which have produced silvered shoots.
} 
(8) Laburnum vulgare and L.. alpinum.--The common Laburnum is mentioned by Güssow (12), Pickering (8), and Brooks (9), as having suffered from Silver leaf disease. Apart

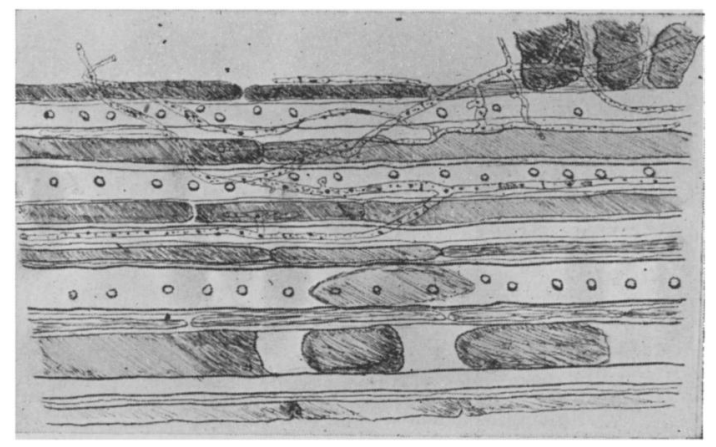

I'ext fig. 7.-Longitudinal section through the wood of a shoot of Kıbes cereum.

from the genus Prunus I have noticed no more extensive destruction on any other ornamental tree or shrub as a result of Stereum purpureum than on Laburnum alpinum. Judging from the damage caused during 1918 in the surburban district of London, where, in certain localities, up to 25 per cent. of the trees developed $S$. purpureum fructifications during autumn and winter, it is highly probable that unless drastic measures are taken the cultivation of Laburnum alpinum will become impossible. So far I have only met one case of a living tree of Laburnum vulgare bearing $S$. purpureum fructifications. A living side-branch of $L$. vulgare about four years old showed discoloration in the wood, a discoloration occupying about $100^{\circ}$ of the circumference, but the extent gradually diminished upwards in the four and three year old wood. On reaching the two-year-old branches it was confined to the cambial region and to about one-third of the circumference, whereas in the one-year-

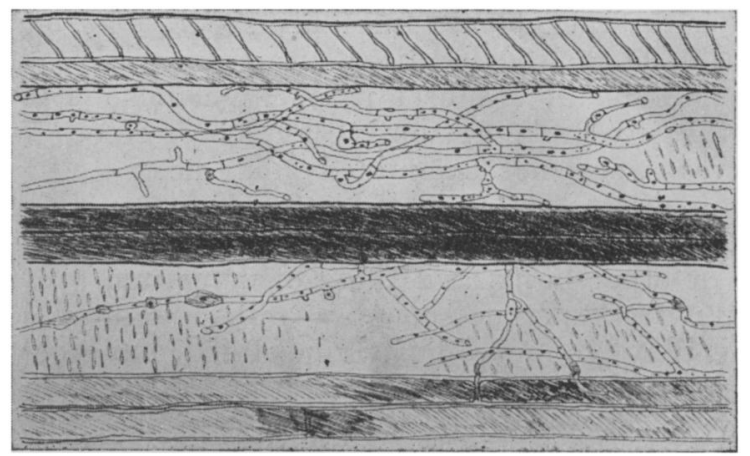

Text fig. 8.-Radial longitudinal section of the xylem vessels of Laburnum vulgare showing deep discoloration and abundant hyphae. 
old twigs (current year's growth) it was reduced to a few continuous streaks.

Abundant hyphae were found growing in all directions in the wood elements (see Text Fig. 8), from the cambial region inwards. The hyphae present in the lumen of the vessels were in every. respect identical with those observed in other hosts, already referred to, and similar to those grown in artificial cultures of Stereum purpureum.

There was no opportunity of examining the roots of Laburnum vulgare, and it is unknown if root infection took place. The faet that the upper set of branches of one half of the tree was killed by the fungus, whereas the lowest branches were apparently normal, indicates that the fungus penetrated through wounds in consequence of pruning, or through the abraded surfaces which frequently occur in the crown of the tree.

\section{III.-Modes of Infection.}

According to Percival (4), Güssow (12), Pickering (8), Brooks (9), the fungus Stereum purpureum is a wound parasite. In order to confirm this view several inoculation experiments were carried out in the laboratory. Pieces of mycelium, fructifications, and spores were placed on uninjured leaves of Prunus lusitanica in Petri dishes. Although the conditions for development of the fungus were most favourable, yet no invasion into the tissue could be observed. If, however, spores, pieces of fructifications and mycelium are laid on leaves which have been scratched with a needle or from which the epidermis has been removed, the penetration of the hyphae into the host soon begins, followed by partial disorganisation of the cells of the leaf. It is clear that the fungus if it can once gain entry can develop in the leaf, and it is hoped to carry out further experiments on this point.

Several plants of Prunus lusitanica were inoculated by placing pieces of mycelium of $S$. purpureum beneath the bark of stem, branches and roots. Within three weeks, discoloration of the cambial region of the wood appeared on both sides of the point of inoculation. In agreement with Brooks, I observed the rapid growth of the hyphae in an upward direction and a very slow progression down the shoot. Precisely the same process results from the insertion of pieces of fructifications or pieces of mycelium in the roots. In the control experiments no effect at all was obtained.

Stem and Branch Infection.-From the actual observations in the laboratory and in the field it would be premature to state at what particular time of the year infection takes place, since it is not yet known how long the spores retain their vitality. The following observation shows that they are capable of immediate germination. An old silvered branch of "Victoria Plum" was taken to the laboratorv in October, and $S$. purpureum fructifications developed upon it within eight days from the day of amputation. Basidiospores taken from these fructifications germinated within 24 hours in hanging-drop cultures. Spores are undoubtedly blown about by the wind and possibly alight on 
open wounds, where, under favourable atmospheric conditions, they germinate and penetrate the host.

Localised silvering of a branch or twig in any shrub or tree originates from local infection through unprotected wounds of branches and twigs. The spreading to other branches follows according to the progressive development of the hyphae inside the tissue; and since the hyphae grow more rapidly in an upward than in a downward direction, the silvering of the uppermost set of branches is explained, whereas the lower placed branches of the same tree may remain healthy for one or two seasons. The few cases known where healthy suckers come up from silvered trees are due to the fact that the hyphae have not yet passed to the root-stock or that the stock used for grafting may be less susceptible or even immune.

Root infection.-Many silvered suckers have been observed developing from normal plum-trees. It is common knowledge that Silver leaf on "Victoria" and other varieties of plums is more prevalent in plantations where the soil is cultivated for catch crops, than it is on grass land. This is probably due to the fact that while cultivating large plantations with a plough, or even a spade, it is difficult to avoid injury to superficial roots. Certain stocks, such as "Brompton" and "Common Plum," when used for grafting, send up every year numerous suckers, the removal of which causes additional injury. Other cases were noticed, where the lowest set of branches from the main stem showed silvering, while the upper branches were normal. No abrasion or jagged surfaces could be seen on any of the diseased branches. The removal of the lowest set of these silvered branches would by no means save the tree, since the discoloration extends to the main stem. A few cases were observed where silvered suckers arose from a plant, the upper parts of which were entirely normal. This strongly indicates root infection, probably through injury to superficial roots.

\section{IV.-Preliminary Preventive Measures for True Silver Leaf.}

Owing to the increase of Silver leaf the fruit-growing industry is seriously threatened, particularlv with regard to our choice varieties of plums, e.g., "Victoria" and "Czar," and soft cooking varieties of apples (already subjected to many other pests), " Lord Suffield," " Bramley's Seedling," "Lord Grosvenor," "Emperor Alexander," which are likely to go out of cultivation. The spreading of the disease to many ornamental trees and shrubs is also causing considerable alarm to growers. Prompt and drastic measures should therefore be taken to stamp it out.

In controlling plant disease one may adopt either curative or preventive measures. Unfortunately up to the present no practical curative measures with regard to Silver leaf are available. As a preventive measure all that one can recommend is good cultivation, using that expression in its widest sense. 
Careless pruning, unsatisfactory drainage and a deficiency of lime are especially to be avoided. The application of artiticial fertilizers, partıcularly those of highly nitrogenous character, induces "soft" growth, with its greater liablity to injury by frost and by insects. It is evident from the observations here put forward that those stone-iruit trees and other trees and shrubs annually subjected to pruning are much more likely to fall victims to Silver leaf than those which are not so treated. Indiscriminate pruning, and the cutting off of old branches for fire-wood, as was done in war-time, pave the way for the entrance of the fungus if the cut surfaces are not immediately treated.

The following primary preventive measures are recommended :-

1. The destruction of Stereum purpureum wherever it occurs, whether it is growing as a parasite or as a saprophyte.

2. If localised silvering in the upper set of branches of a tree is noticed, the silvered branches should be cut off without delay below the limit of discoloration of the wood. Many trees have been saved from total destruction where this method has been followed. Should, however, the lowest branches of a tree be affected, there is little hope of recovery, since the fungus is then present in the main stem. Such trees should be grubbed up before the fructifications develop, usually about September.

3. Whenever a branch is amputated, it is essential that the branch should be cut off as near as possible to the main stem or to the point of origin in order to encourage more rapid "callusing." A clean cut with a knife should follow the saw, especially where a jagged surface has been left. When pruning branches of the hosts mentioned on pp. 242, 243 of this paper, the cut surface should be protected immediately, thus preventing the spores of the fungus, which are blown about by the wind, from penetrating the host. Stockholm tar or its equivalent being one of the cheapest substances for protecting the wounded surface can be used for commercial purposes, whereas on a small scale, grafting-wax may be employed.

4. Removal of all dead and diseased wood from the plantation, since the fungus in the wood will soon develop fructifications, the spores from which are a great danger to the trees in the vicinity. Diseased branches should not be used for fencing, as this involves the same danger as when left in piles in the orchards. Storing of the wood under such dry conditions as prevent the development of the fungus should be aimed at. An alternative method, which may be adopted in large plantations, is the conversion of such cut off branches into charcoal in the field.

5. In plantations where the plough is used for catch crops, it is difficult to prevent injury to superficial roots, but additional injury by the spade may be minimised by a careful use of that implement, and by the pulling up of suckers.

6 . Varieties of plums grown on their own roots produce only a few or scarcely any suckers, and hence the planting of such varieties is advisable whenever circumstances permit.

7. The planting of resistent or less susceptible varieties of 
plum, such as "Yellow Pershore Plum" (sometimes called "Yellow Egg Plum") and "Early Rivers," is highly to be recommended.

8. The soft cooking varieties of Apples are more susceptible to Silver leaf than others, the latter should therefore preferably be planted.

9. Certain stocks, such as the "Brompton" and "Common Plum," are highly susceptible to this disease, whereas the "Yellow Pershore" is more or less resistent, and, in addition, possesses other valuable qualities.

10. Pruning of ornamental trees and shrubs known to be affected by this malady should be discontinued, unless the cut surfaces can be protected immediately after the operation.

11. When replanting infected orchards precautions should be taken to avoid the varieties of trees mentioned on page 242, since these varieties have proved susceptible to " true Silver leaf." An alternative to this is the interplanting in Plum orchards of Pear trees, or Cob-nuts and Filberts.

\section{General Discussion.}

The results described in the present contribution clearly support the view that Stereum purpureum is the main cause of Silver leaf. Cases of Silver leaf, however, are here described in which no trace of the fungus could be detected in any part of the plant.

It is suggested that silvering caused by Stereum purpureum should be called "True Silver leaf," and the term "False Silver leaf" be applied to those cases where the fungus is absent, the cause being apparently some physiological weakness.

In July, 1918, a plant of Camellia Sasanqua var. was observed in a pot in the Temperate House, Kew Gardens, which exhibited marked silvering of the leaves. The roots, branches, and twigs of this plant were examined, but no trace of hyphae were found. Local discoloration in the cells of the various tissues was observed here and there, but a continuous streak was never perceptible. Hand and microtome sections, both longitudinal and transverse, of petioles and leaves, failed to reveal any fungal threads. In hand sections no separation of the tissues occurred, indicating that there had been no dissolution of the middle lamella. In comparison with normal leaves, a waxy deposit of the colour of white lead is secreted by the affected leaves, and this gives a silvery appearance when the leaves are seen from a distance. There was also a reduction of chloroplasts in these leaves as compared with the healthy ones.

"False Silver leaf" is also to be found on a few varieties of Apples, the variety "Grenadier," already mentioned, and "Bramley's Seedling." It has also been observed on Koelreuteria paniculata, Saxm., on cultivated varieties of Cherries, Peaches and Plums. False Silver leaf is probably due to some physiological disturbance of the plants, possibly induced by unsuitable treatment. Plants of Koelreuteria which showed this false Silver leaf during one or two seasons, were observed to regain their normal colour under improved cultural treatment. 
Silvering is more common, according to my observations, where the drainage is bad and where there is a deficiency of lime in the soil. If the trees are top-grafted on an unsuitable stock, the chances of the occurence of false Silver leaf appear to be increased.

The following table indicates the distinction between true and false Silver leaf :-

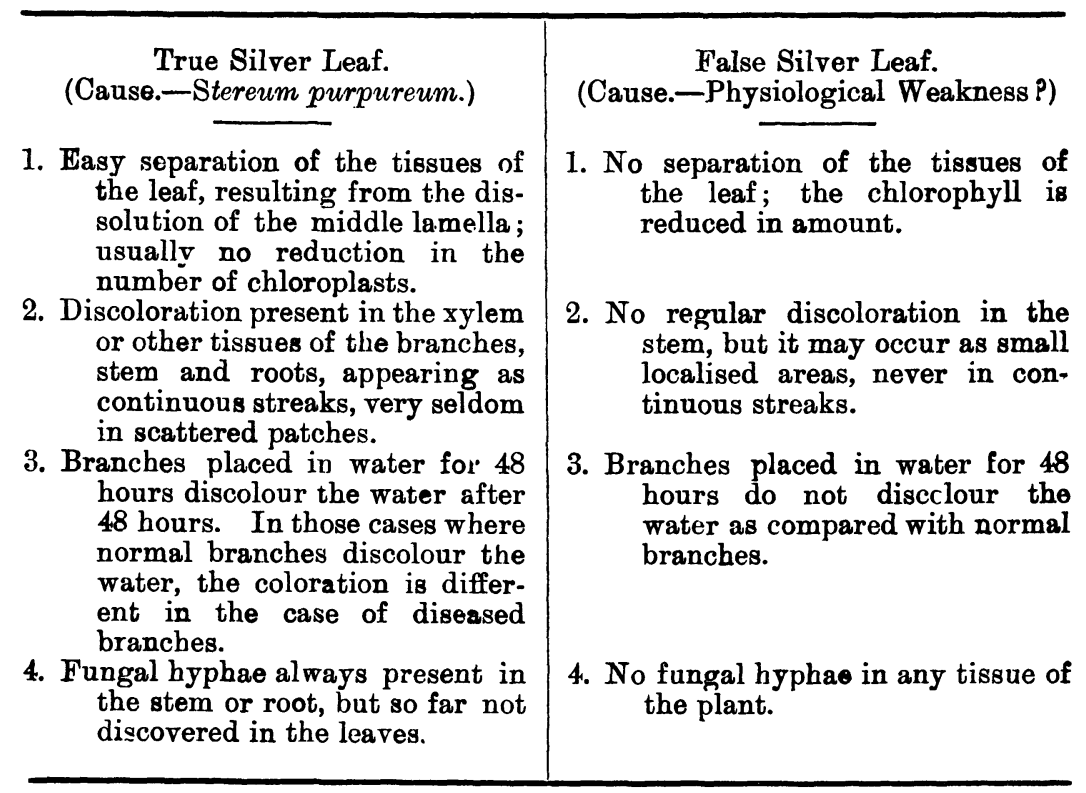

It should be noted that it does not necessarily follow that in every part of a true silvered plant all four distinguishing characters would be met with. When dealing with plants which in normal conditions discolour water, care must be exercised that branches or twigs of equal size are taken and the capacity of the ressel considered.

As far as published evidence goes, no mention has been made of " False Silver leaf" by any writer on the subject. Brooks, however, observed a plant of Lamium album exhibiting Silver leaf with a shrivelled epidermis, which could easily be separated from the mesophyll cells, but he concluded that the silvering in this case could not be attributed to Stereum purpureum. Brooks also draws attention in his second paper to the confusion of Silver leaf with Chlorosis when dealing with applications of iron compounds to restore normal growth. It is therefore very difficult to comment on the work of those who hold the physiological theory of the cause of Silver leaf, but according to the work of Prilleux (1), Sorauer (2), Alderhold (3), and Massee (5), it is obvious from their descriptions that they were dealing with True Silver leaf, although these writers invariably interpreted the disease as of non-parasitic nature. A considerable amount of material is required for successful investigation, particularly fair-sized twigs and branches, since the hyphae only in extreme cases approach the terminal bud of the current year's growth. 
The fact that no hyphae are to be found in the leaves of plants suffering from True Silver leaf has no doubt led these authors to the non-pathogenic theory of the disease. At that time also the fungus Stereum purpureum was considered a saprophyte, and it is apparently only during recent years that its virulence as a parasite has increased and has spread to plants belonging to various natural orders. In the case of Neviusia alabamensis and Spiraea japonica var. glabrata, described here, the hyphae would have certainly been overlooked, if the examination had been confined to the apical shoots.

In addition to the literature on Silver leaf mentioned in this paper I have been unable to find anv evidence as to bacteria being the cause of Silver leaf, as referred to by Blackmore (7), in his report. It is obvious that soil and atmospheric conditions or other environmental factors of a greenhouse are capable of causing physiological injury to the plant, but up to the present there is no evidence indicating parasitic bacteria as the cause of either True or False Silver leaf.

It is interesting to note that the partial disorganisation of a tissue, as a result of the dissolution of the middle lamella, in which fungal hyphae are not present-which is normal to the Ieaves of silvered plants-is also found in the silvered twigs of Prunus triloba, var. flore pleno. There the bast shows partial disorganisation, although the hyphae are confined to the cambial region.

Since enzymes are apparently colloidal substances which would diffuse with difficulty through cell-walls; the most satisfactory explanation of the changes in the leaf, seems to be the one suggested to me by Professor V. H. Blackman, that some diffusible poisonous substance is produced during the metabolic processes of the fungus or of the jnvaded cells of the host; this substance is then conveyed to the leaves by the water conducting channels, where it causes a change in the activity of the enzymes capable of acting on the middle lamella of the wall. A similar reaction apparently takes place in the bast of Prunus triloba var. flore pleno.

In the experiments already described where pieces of mycelium, or fructifications or spores, were placed on injured leaves of Prunus lusitanica in petri dishes, the hyphae were found to have penetrated the leaves in about 12 days, without, however, causing a falling asunder of the tissues. The dissolution of the middle lamella therefore does not seem to be due to direct action of the fungus, at least in its early stages, but rather to the result of the interaction of the metabolisms of the fungus and bast cells of the twig. Whether infection can also take place in rature in injured leaves is yet unknown.

The appearance of the discoloration varies with the different host plants. In all the cases examined, the discoloration of the host tissue extended beyond the limit of the hyphae. Brooks' observations on the discoloured wood of plum trees were confirmed by placing pieces of the fructifications or ordinary mycelium from artificial cultures on sterilized blocks of plum wood. In four days a definite discoloration of the wood was to be observed; when 
three weeks later the block of wood was examined no hyphae could be found towards the edge of the discoloured area. To avoid confusion between the discoloration produced by the fungus and that resulting from oxidases, the material was steeped in boiling water for ten minutes before being cut into sections.

With regard to the general characteristics of Stereum purpureum, it was found that this fungus varies considerably in colour and in external characters. It differs apparently according to whether it has been growing parasitically or purely saprophytically, for the fructifications on Salix have distinctly smaller spores than those on Plum and Apple. However, for the present, the fungus must be treated as a single polymorphic species, as only definite evidence afforded by a series of careful investigations would justify the division of the species into distinct forms. S. purpureum is found growing as a saprophyte on the dead wood of the following genera: Betula, Corylus, Fagus, Ulmus, Genista, Salix, etc. There can be no question that the fungus was less detrimental in past years, and it is only during the last twenty years that its virulence has gradually increased to such an extent that the disease is now of almost epidemic nature. Whether the purely saprophytic form of $S$. purpureum growing on the hosts mentioned above are able to cause "Silver leaf" remains to be proved," but it is certain that mycelium or pieces of fructifications from Betula, Genista and Saliv when inoculated into Plum and Apple trees will cause discoloration of the wood, indieating that the hyphae have developed in the tissues.

The fungus can apparently only enter a living plant by open wounds, and is capable of attacking a great number of woody species, belonging to various natural orders, infection taking place both through the stems and superficial roots. It is facilitated by pruning, particularlv when the wounds are left unprotected, and also by any mechanical injurv of an exposed part of the tree, or as a result of injury to superficial roots.

With regard to the distribution of mycelium, no hyphae have been detected in the lamina or petiole of leaves in any " silvered" plant, either by the author or any previous workers. In the bast of affected twigs of Prunus triloba var. flore pleno, abnormal air spaces are to be found, and a dissolution of the middle lamella which leads to a falling asunder of the tissues, similar to that found in the leaves of plums. No hyphae, however, were observed. It is evident therefore that under some circumstances the fungus is able to exert in the stem the same injurious action at a distance which is common in the leaf.

\section{VI.-Summary and Conclusions.}

The present investigations lead to the conclusion that there are two types of Silver leaf, namelv, (1) True Silver leaf, by far

* The inoculation experiments which are in progress at the Royal Horticultural Society Gardens, Wisley, definitely prove that the forms of S. purpureum found growing as a pure saprophyte are capable of producing Silver leaf, and with the same virulence upon various host-plants as those of S. purpureum growing parasitically. 
the most common, and caused by the fungus Stereum purpureum, and (2) False Silver leaf, which is comparatively rare, and due apparently to the result of some physiological weakness. It is difficult to distinguish the tro forms by external examination, as the appearance of the foliage is practically identical. True Silver leaf however is characterised by a dark discoloration of the wood when seen in cross-section, and a ready peeling off of the upper epidermis of the leaf.

The principal features of the True Silver leaf are as follows: The normal green colour is hidden by the presence of air spaces under the cuticle, which causes a reflection of the light, and brings about the silvery appearance. There is usually no reduction in the number of chloroplasts. As a result of the dissolution of the middle lamella of the cell walls of the leaf, the leaf tissues easily fall apart when the leaf is sectioned. The dissolution of the middle lamella is perhaps brought about by the production of some diffusible poisonous substance during the metabolic process of the fungus and of the invaded cells of the host; this substance is then conveyed to the leaves by the water conducting channels, where it causes a change in the enzymes capable of dissolving the pectic substances of the cell-wall. Affected plants moreover nearly always show continuous streaks of dark brown discoloration in the woody tissues of the stem, branches, twigs or roots, which when examined microscopically, reveal the presence of exceeding fine filaments of $S$. purpureum. Branches suffering from True Silver leaf, when placed in water for 48 hours cause the discoloration of the water, the degree of discoloration depending on the severity of the attack.

Initial infection takes place above ground and also immediately below the ground level, and so far as the present investigations are concerned, the fungus can only gain entrance through open wounds. Recent inoculation experiments (the results of which will be published later) confirm the view that injured superficial roots can be infected; the frequency of infection probably depends on the variety of the stock used for orafting. Localised silvering of a branch results from local infertion, which has not yet spread to the main stem. Silvered suckers originating from a healthy tree indicate root infection, whereas the occurence of healthy suckers from diseased plants points to crown or stem infection, since the mycelium has not yet reached the root system. The following plants have been examined, all of which suffered from True Silver leaf: "Victoria Plum " (and the stocks upon which it is usually grafted, e.g., the "Brompton" and "Common Plum"), Prunus lusitanica, P. triloba var. flore pleno, among Apples the varieties "Lord Grosvenor" and "Bramley's Seedling," Spiraea japonica var. glabrata, Neviusia alabamensis, Ribes cereum, Laburnum alpinum and L. vulgare. Although fructifications of $S$. purpureum have not been noticed in Ribes cereum and Spiraea japonica var. glabrata, yet the hyphae observed in the tissues were identical with the hyphae of that fungus grown in artificial cultures. In view of the frequency and the disastrous effects of True Silver lcaf, and its increasing worldwide importance, the author of this paper recommends the ex- 
termination of Stereum purpureum wherever it occurs. This is further advisable since it is known that the saprophytic forms have the same injurious effect when inoculated into living trees as those found parasitically. Preliminary measures of a preventive nature are described.

False Silver leaf is much less prevalent than True Silver leaf. It is easily distinguished by certain microscopic characters. The leaves show a reduction in chloroplasts, which gives them a silverlead colour from a distance; there is however, no dissolution of the middle lamella, and no falling apart of the cells. No hyphae have been observed in any part of a diseased plant. There are no continuous streaks of discoloration to be observed in the wood, and cut-branches do not discolour the water when placed in it. The former is perhaps the only reliable "field" character. False Silver leaf is occasionally found in apples, "Grenadier," "Bramley's Seedling," C'ameliia Śasanqua var., Eoelreuteria paniculata, and rarely on cultivated varieties of Cherries, Peaches and Plums. Trees and shrubs which have suffered from False Silver leaf for one or two seasons have been noted to resume their normal appearance the following year when improved cultural treatment has been applied.

The microscopic examinations and the primary preparations for the inoculation experiments were carried out under the personal supervision of Prof. V. H. Blackman, to whom I am much indebted for assistance and valuable suggestions in many directions.

\section{BibLiography.}

1. Prillieux, Ed. Le Plomb des arbres fruitiers. Bull. d. séances d.l. Soc. Nat. d'Agric. de France. 1885.

2. Sorauer, P. Milchglanz. Handbuch der Pflanzenkrankheiten. 2. Autlage. Band 1. p. 141. Berlin 1886. 3. Auflage. Band 1. p. 285-286. Berlin 1909.

3. Aderhold, R. Milchglanz des Steinobstes. Zeitschrift der Pflanzenkrankheiten. Bd. 5 p. 86.

4. Percival, J. Silver leaf Disease. Journal Linnean Society. Botany. Vol. 35, p. 390.

5. Massee, G. Conference on Fruitgrowing. Journal of Roy. Hort. Soc. Vol. 30, p. 35. "Silver leaf." Diseases of cultivated plants and trees. London. 1910.

6. Delacroix, G. Maladies des plantes non-parasitaires. Vol. 1, p. 227.

7. Blackmore, G. C. Annual Report for New Zealand, Depart. of Agriculture. 1909. p. 53.

8. Pickering, S. U. 6th Report Woburn Experimental Fruit Farms. 1906. 12th Report Woburn Experimental Fruit Farms. 1910.

9. Brooks, F. T. Silver leaf disease. Journal of Agricultural Science. Vol. IV., p. 133. Journal of Agricultural Science. Vol. 5, p. 288. 
10. Güssow, H. T. Report of Dominion Botanist. Department of Agriculture for Canada, 1910. p. 268. Zeitschrift für Pflanzenkrankheiten. Vol. XXII. Heft 7. p. 385. 1912.

11. Smolak, Jar. Annals of Applied Biology. Vol. II., p. 138. 1915.

\section{Explanation of Text Figures.}

All the figures have been reduced bv one half for reproduction.

1. Longitudinal section through the wood of a silvered sucker of " Brompton Stock," showing hyphae of S. purpureum in a vessel, with two distinct clamp connections. $\times 1000$ times.

2. Longitudinal section through the wood of Prunus triloba var. flore pleno, showing hyphae of $S$. purpureum in the xylem vessels bordering the cambium. In one case the hyphae pass through the discoloured area. The cambium cells have fallen apart. $\times 1000$ times.

3. Longitudinal section through the wood of a silvered Apple (said to be "Bramley's Seedling"), showing abundant hyphae in the wood vessels, with numerous clamp connections. The hyphae are unusually irregular in form. $\times 1000$ times.

4. Longitudiual section of a silvered branch of Spiraea japonica var. glabrata, showing the hyphae in the wood vessels. $\times 1000$ times.

5. Longitudinal section of a diseased root of Neviusia alabamensis, showing presence of hyphae and alternate discoloration of the cells. $\times 1000$ times.

6. Longitudinal section of a silvered shoot of Neviusia alabamensis, with hyphae in the xylem vessels. $\times 1000$ times.

7. Longitudinal section of a silvered shoot of Ribes cereum, showing the hyphae and pronounced discoloration in the wood vessels. $\times 1000$ times.

8. Radial longitudinal section of the xylem vessels of Laburnum vulgare, showing deep discoloration and abundant hyphae of $S$. purpureum. $\times 1000$ times.

\section{Drschiption of Plate VIII.}

FIG. 1. A sterilized block of Plum wood upon which a piece of Stereum purpureum had been placed. The figure shows that the discoloration extends beyond the region of the hyphae; (1) indicating the extent of the discoloration, (2) the limit of hyphae, and (3) the portion of fructification placed on the wood.

, 2. Branch of Prunus lusitanica, showing silvering and curling of the leaves. The letter $x$ indicates that the upper epidermis has been detached from the palisade cells. 
Fig. 3. A sucker of "Common Plum" stock, showing parallel, sometimes tortuous streaks of discoloration.

, 4. Fructifications of S. purpureum growing on a living branch of Prunus triloba var. flore pleno.

, 5. Fructifications of $S$. purpureum growing on a living branch of Apple tree said to be " Bramley's Seedling."

\section{XVII.-DIAGNOSES AFRICANAE: LXXII.}

1631. Kalanchoe densifiora, Rolfe [Crassulaceae]; affinis $K$. crenatae, Harv., sed floribus minoribus et cymis densioribus distincta.

Herba succulenta, erecta, glabra, 0.5-1.1 m. alta. Caulis simplex, strictus, crassiusculus, subteres. Folia opposita, petiolata, ovata, obtusa, crenata, viridia, 7-10 cm. longa, 6-7.5 $\mathrm{cm}$. lata; petioli circiter $1 \mathrm{~cm}$. longi. Cymae pedunculatae, erectae, $3-5 \mathrm{~cm}$. latae, densiflorae, in paniculam corymbosam 10 $12 \mathrm{~cm}$. latam dispositae. Bracteae lineares, acutae, 4-5 $\mathrm{mm}$. longae. Pedicelli circiter $3 \cdot \mathrm{mm}$. longi. Calyx 4-partitus, 5 $\mathrm{mm}$. longus; lobi subulati, acuti, 5-6 mm. longi. Corollae tubus $1 \mathrm{~cm}$. longus, basi ventricosus, superne tubulosus; lobi ovati, apiculati, $3 \mathrm{~mm}$. longi, flavi, margine incurvi. Stamina inclusa.

Tropical Africa. British East Africa: Limuru, $2250 \mathrm{~m}$. , in short grass and bushland, J. D. Snowden 556. Said to be erect or nearly so, 2 to $4 \mathrm{ft}$. high, and with yellow or reddish flowers.

1632. Anisophyllaea tomentosa, Rolfe [Rhizophoraceae]; affinis $A$. fruticulosae, Engl. et Gilg., sed major et foliis fere duplo longioribus differt.

Ramosissima, ramis juvenilibus dense ferrugineo-tomentosis, vetustis cinereis et striolatis. Folia breviter petiolata, elliptica vel ovato-elliptica, obtusa vel subobtusa, basi cuneata, coriacea, primo dense ferrugineo-tomentosa, supra mox subglabra, subtus tomentosa, $5-8 \mathrm{~cm}$. longa, $2-4.5 \mathrm{~cm}$. lata, 5 -nervia, jugis 2 lateralibus prominentibus arcuatis et fere ad apicem extensis, venis reticulatis; petioli circiter $5 \mathrm{~mm}$. longi. Spicae axillares, numerosae, ferrugineo-tomentosae, $5-8 \mathrm{~cm}$. Iongae. Flores sessiles, numerosi, globosi, ferrugineo-tomentosi. Sepala late ovata, 1-1.5 $\mathrm{mm}$. longa. Petala $1.5-2 \mathrm{~mm}$. longa, basi oblonga, apice in laciniis filiformibus profunde fissa, lobis involutis. Fructus ellipsoideus, sulcatus, circiter $2 \cdot 3 \mathrm{~cm}$. longus, $1 \cdot 3 \mathrm{~cm}$. latus.

Tropical Africa. Angola: Malange district, Gossweiler 1395, 1396 ; Bailundo district, Benguella, $1530 \mathrm{~m}$. , Wellman. Belgian Congo: at Katanga, Ringoet 56. Native name, "Mufungo."

1633. Scyphosyce pandurata, Hutchinson [Moraceae]; affinis S. Mannianae, Baill., sed ramulis glabris cortice brunneo transverse rupto, foliis e medio ad basin abrupte angustatis superne late ovatis et sensim acuminatis differt. 